\title{
Determination of biological markers of organic substances in sediment and soil samples by gas chromatography
}

\author{
Nemanja Koljančića, Olga Vyviurska ${ }^{\mathrm{a}}$, Milica Balaban ${ }^{\mathrm{b}}$, Ivan Špánik $^{\mathrm{a}}$ \\ ${ }^{a}$ Institute of Analytical Chemistry, Faculty of Chemical and Food Technology, \\ Slovak University of Technology in Bratislava, Radlinského 9, Bratislava, 81237 Slovakia \\ ${ }^{b}$ Faculty of Natural Sciences and Mathematics, University of Banja Luka, \\ Mladena Stojanovića 2, Banja Luka, 78000 Bosnia and Herzegovina \\ ivan.spanik@stuba.sk
}

\begin{abstract}
Once they reach the environment, petroleum hydrocarbons undergo various chemical, physicochemical and biochemical transformation processes. Organic compounds which are not or are very poorly subject to these processes are thermodynamically the most stable isomers and they are called biological markers (biomarkers). This paper presents the results of the determination of organic substances in twelve samples taken in the area of the city of Banja Luka (Bosnia and Herzegovina). Two soil samples were taken in the Banja Luka city heating plant area and ten river sediment and soil samples were taken in the upper and lower basin of the Vrbas river in the Banja Luka city area. The aim of this study was to determine the biomarkers of oil-type pollutants in contaminated samples as well as the type of organic substances in samples taken near the contaminated area. Assisted solvent extraction was used to isolate the total petroleum hydrocarbons (TPH) from all twelve samples. Fractionation of the extracts into saturated and aromatic hydrocarbon fractions was performed by column chromatography. The fractions were analyzed by gas chromatography-mass spectrometry (GC-MS). On basis of the obtained chromatograms, biomarkers of petroleum pollutants and specific correlation parameters of organic substances in the samples were determined. The dominance of $n$-alkanes with odd $\mathrm{C}$ atoms as well as the presence of an unresolved complex mixture (UCM) on chromatograms of saturated and aromatic hydrocarbons showed the presence of anthropogenic organic substances of petroleum origin in the analyzed samples. Based on the obtained chromatograms, it can be concluded that microbial degradation of hydrocarbons in all samples occurred.
\end{abstract}

Keywords: organic substances, hydrocarbon composition, biomarkers, GC-MS analysis, correlation parameters, assisted solvent extraction

\section{Introduction}

Hydrocarbons found in soil and sediments reflect both natural and anthropogenic inputs as well as diagenetic processes taking place in the water column and during transport and sedimentation (Shirneshan et al., 2016). Crude oil consists mainly of a complex mixture of hydrocarbon compounds (aliphatic and aromatic) and non-hydrocarbon compounds (resins and asphaltenes). Environmental contamination occurs frequently and it is associated with production processes, refining, transportation and storage of oil and petroleum products. Oil undergoes various transformation processes in the environment conditions, depending on the physicochemical and biological factors such as evaporation, dissolution, microbial degradation, photooxidation and interaction between oils and sediments (Faboya et al., 2016). Lower molecular weight hydrocarbons normally evaporate, while heavier compounds, such as asphaltenes and resins, partially undergo deposition in sediments (Kakhki et al., 2018; Yogaswara et al., 2020). Therefore, these compounds are frequently found in petroleum, coal, sedimentary rocks, recent sediments, and soils. Molecular structures of stable geochemical products can be attributed to biogenic precursor molecules. At the same time, conversion from biogenic and thermodynamically less stable compounds to more stable ones is especially interesting in isomers and stereoisomers (Hazra et al., 2019). From the chemical point of view, a majority of biomarker molecules belong to aliphatic or aromatic hydrocarbons (Walters et al., 2018; He et al., 2018; Kao et al., 2018). Thus, hydrocarbon composition of petroleum has been extensively used for the determination of hydrocarbon sources in coastal sediments and soils. A heating plant in the Banja Luka city still uses heavy oil fractions like mazut as a heating medium. Thus, the objectives of the present study are: (i) to determine the occurrence, distribution and source of saturated and aromatic hydrocarbons, (ii) to examine the distribution, composition, and relative maturity levels of saturated and aromatic hydrocarbons in sediments and soils, and (iii) to evaluate the degree of microbial degradation of organic sub- 
stances in analyzed samples. Twelve sediment and soil samples were taken for analysis in the area of the city of Banja Luka within the heating plant and in the lower and upper basin of the Vrbas river. The fractions of saturated and aromatic hydrocarbons were analyzed by the GC-MS method to determine the specific correlation parameters, e.g. the degree of maturation and origin of the organic substances.

\section{Material and Methods}

\section{Chemicals}

Dichloromethane, $n$-hexane, elemental copper and sodium sulfate were purchased from Merck (Darmstadt, Germany). Florisil ${ }^{\circledR}$ was obtained from Fluka AG (Buchs, Switzerland) and acetone was obtained from Mikrochem (Pezinok, Slovakia).

\section{Sampling}

Exact sampling locations are shown in Fig. 1. Totally twelve samples were studied in this work, while two were taken in the Banja Luka city heating plant area - samples 1 and 2. Other ten samples represent river sediment samples and soil samples taken in the upper and the lower basin of the Vrbas river in the Banja Luka city area. All samples were air-dried for 24 hours and sieved through $0.063 \mathrm{~mm}$ sieves.

\section{Total petroleum hydrocarbons extraction}

Extraction of total petroleum hydrocarbons (TPH) from sediment and soil samples was performed by assisted solvent extraction using the Dionex ASE 150 apparatus. Extraction cells were filled with $28 \mathrm{~g}$ of previously air-dried and sieved samples and the extraction was accomplished according to a previously established method (Thermo Fisher
Scientific Inc., 2011). Dichloromethane/acetone (1:1) mixture was used as an extraction solvent, and the following conditions were set: extraction temperature of $175^{\circ} \mathrm{C}$, static time of $5 \mathrm{~min}$, flush volume of $60 \%$, gas purging time of $100 \mathrm{~s}, 1$ static cycle. The obtained extract volume was reduced to $5 \mathrm{~mL}$ using a rotary evaporator. Activated copper powder was added to the extract and it was sonicated for $3 \mathrm{~min}$ in order to remove elemental sulfur from the sample extracts.

\section{Fractionation of total petroleum hydrocarbons extracts}

Column chromatography was used to separate the TPH extract into the saturated and aromatic hydrocarbons fractions using $2.5 \mathrm{~g}$ of Florisil $^{\circledR}$ and $0.2 \mathrm{~g}$ of sodium sulfate, both activated at $130{ }^{\circ} \mathrm{C}$ for $24 \mathrm{~h}$, as adsorbents. The column was loaded with $1 \mathrm{~mL}$ of the extract which was previously conditioned with $10 \mathrm{~mL}$ of $n$-hexane. The saturated hydrocarbon fraction was eluted with $5 \mathrm{~mL}$ of $n$-hexane while the aromatic hydrocarbon fraction was eluted with $3 \mathrm{~mL}$ of dichloromethane.

\section{GC-MS analysis}

The fractions of saturated and aromatic hydrocarbons were analyzed using gas-chromatography/ mass-spectrometry (GC-MS). For this purpose, an Agilent 7890A gas chromatograph with an Agilent 5975C Mass Selective Detector (MSD) was used. Large volume of aliquots was injected in a programmed temperature vaporizer $(\mathrm{PTV})$ in $5 \mu \mathrm{L}$ portions with a repetition of ten times (total aliquot volume was $50 \mu \mathrm{L}$ ) onto a HP-1ms capillary column $(30 \mathrm{~m} \times 0.250 \mathrm{~mm}$ i.d. $\times 0.250 \mu \mathrm{m}$ film thickness $)$. The inlet temperature program was set as follows:
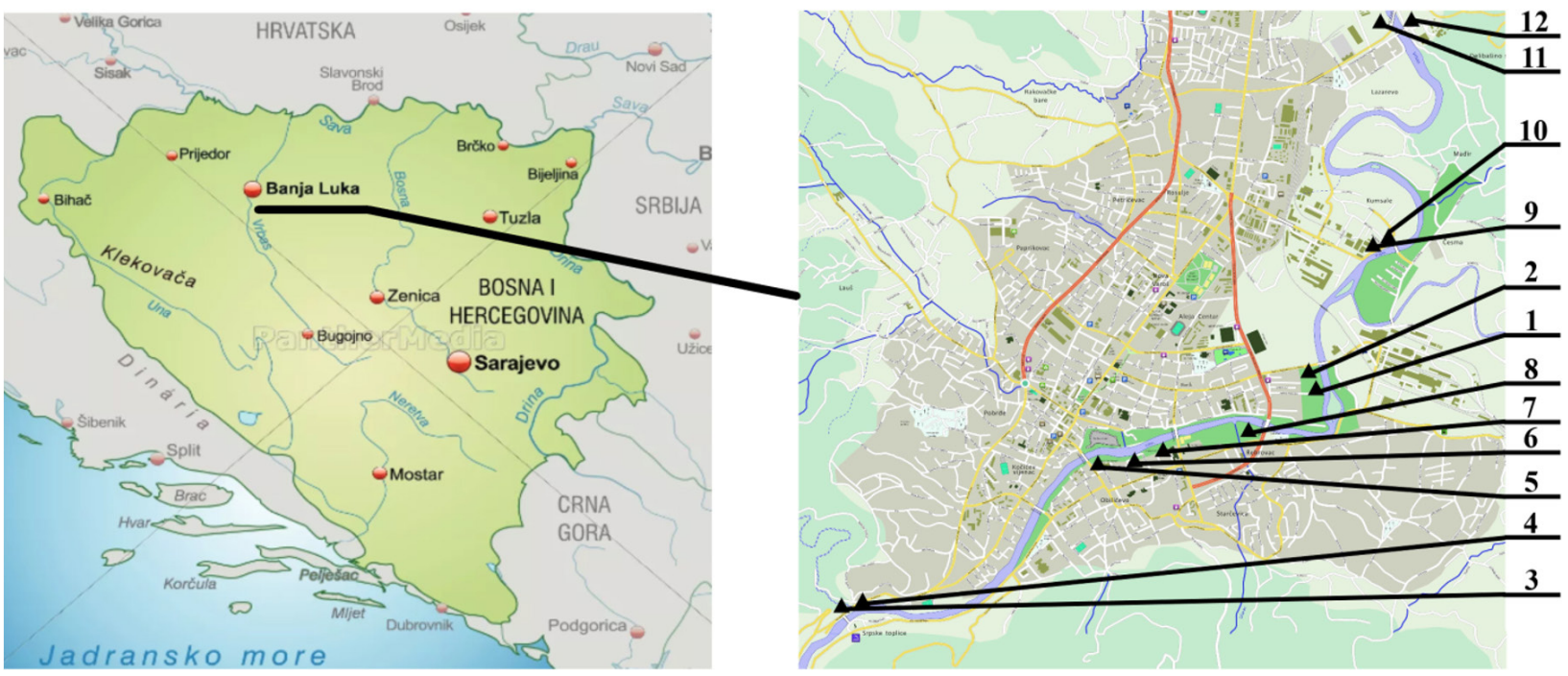

Fig. 1. A map of Bosnia and Herzegovina (left) and a map of the sampling locations in the area of the city of Banja Luka (right). 
$40{ }^{\circ} \mathrm{C}(2 \mathrm{~min})$ up to $300{ }^{\circ} \mathrm{C}(5 \mathrm{~min})$ at $600{ }^{\circ} \mathrm{C} \mathrm{min} \mathrm{m}^{-1}$. Helium (99.999 \% purity) was used as a carrier gas at the flow rate of $1 \mathrm{~mL} \mathrm{~min}^{-1}$. The oven temperature program was set as follows: $40^{\circ} \mathrm{C}$ up to $50{ }^{\circ} \mathrm{C}(7 \mathrm{~min})$ at $100{ }^{\circ} \mathrm{C} \mathrm{min}^{-1}$, and to the final temperature of $300{ }^{\circ} \mathrm{C}(15 \mathrm{~min})$ at $10{ }^{\circ} \mathrm{C} \mathrm{min}^{-1}$. Duration of the measurement was $47.1 \mathrm{~min}$. The transfer line temperature was set to $300{ }^{\circ} \mathrm{C}$, MS source temperature and MS quadrupole temperature were $230{ }^{\circ} \mathrm{C}$ and $130{ }^{\circ} \mathrm{C}$, respectively. Mass spectra were analyzed using the MSD ChemStation software with NIST14, MPW2007 and W9N11databases.

\section{Results and Discussion}

\section{Total petroleum hydrocarbons content}

Results of assisted solvent extraction are shown in Tab. 1. Concentration of TPH extracts ranged from $0.1786 \mathrm{mg} \mathrm{g}^{-1}$ to $25.8214 \mathrm{mg} \mathrm{g}^{-1}$. An increase in the TPH concentration in samples 1 and 2 was expected because both sample places are located in the area of the city heating plant. Similar concentration of TPH was observed for samples $3,4,5,6,7$ and 8 , from the upper basin of the Vrbas river (before the heating plant). In samples 9 and 10 from the lower river basin (after the city heating plant), a decrease of TPH concentration was observed. This effect is probably due to the dilution with the tributary effluents. A contribution of anthropogenic contamination to the total TPH concentration is clearly visible for sample 11 collected at a site located in the industrial zone.

Tab. 1. TPH concentration in samples.

\begin{tabular}{cc}
\hline Sample & TPH concentration $\left(\mathrm{mg} \mathrm{g}^{-1}\right)$ \\
\hline 1 & 25.8214 \\
2 & 19.2857 \\
3 & 0.2500 \\
4 & 0.2500 \\
5 & 1.7143 \\
6 & 1.1786 \\
7 & 0.8214 \\
8 & 0.6786 \\
9 & 0.1786 \\
10 & 0.2143 \\
11 & 2.6071 \\
12 & 0.7143 \\
\hline
\end{tabular}

\section{Saturated hydrocarbons}

Chromatograms obtained for specific $m / z 71$ ratio characteristic for $n$-alkanes of the most contaminated samples (no. 1 and 11) are shown in Fig. 2. Specific correlation parameters of saturated hydro- carbons are shown in Tab. 2. n-Alkane compounds in all samples ranged from $\mathrm{C}_{12}$ to $\mathrm{C}_{35}$. Carbon preference index (CPI) values, representing the ratio of odd to even $n$-alkanes, was found to be in the range from 1.3881 to 2.6383. CPI values close to 1 indicate petroleum and other anthropogenic substances e.g. from the combustion of fossil fuels, wood and agricultural debris (Faboya et al., 2016). The dominance of hydrocarbons with an odd carbon number also indicates the presence of organic substances of anthropogenic origin. Furthermore, organic substances in the sediment and soil samples could originate from native organic substances and oil-type anthropogenic organic substances (Samelak et al., 2018). The presence of unresolved complex mixture (UCM) on $n$-alkane chromatograms is associated with the presence of aromatic heterocyclic compounds formed by the biological degradation of hydrocarbons ( $n$-alkanes, steranes and terpanes) (Romero, et al., 2015; Di Gregorio et al., 2016; Catania et al., 2018; Wang et al., 2018). This group of compounds is typical for samples that have undergone microbial degradation of organic substances (Romero, et al., 2015; Di Gregorio et al., 2016; Catania et al., 2018; Wang et al., 2018). Separation of UCM is commonly a challenge for the $1 \mathrm{D}$ gas chromatographic method. Pristane and phytane are isoprenoid alkanes usually derived from phytyl side-chains in chlorophyll (Tissot and Welte, 1984; Vitorović and Jovančićević, 2016). Due to their high resistance to microbial and thermal degradation, these compounds can serve as biomarkers for fossil fuels. Pristane and phytane can be used to assess the degradation level of petroleum residues (Samelak et al., 2020). Low values of Pristane/Phytane ( $\mathrm{Pr} / \mathrm{Ph})$ ratios (0.9601-1.2771) were found in all samples; $\mathrm{Pr} / \mathrm{Ph}$ values below or near 1 indicate the presence of anthropogenic organic substances of petroleum origin (Rushdi et al., 2017; Zhu et al., 2018; Gdara et al., 2020). Furthermore, based the UCM profile and the $\mathrm{Pr} / \mathrm{Ph}$ ratios, it can be concluded that the samples are contaminated with fresh and partially biodegraded hydrocarbons (Cabrerizo et al., 2016; Iheonye et al., 2019; Zhu et al., 2018). Values of $n$-alkanes/isoprenoid homologs ratios, $n$ - $\mathrm{C}_{17} / \mathrm{Pr}$ and $n-\mathrm{C}_{18} / \mathrm{Ph}$ ranged from 1.1449 to 3.3875 and from 1.1695 to 4.3249 , respectively, which indicates the dominance of $n$-alkanes over isoprenoid alkanes in all samples. Although the microbial degradation of $n$-alkanes proceeds much faster than that of isoprenoid alkanes of pristane and phytane type, the results indicate increased concentration of petroleum hydrocarbons contributing to the total $n$-alkane concentration. At the same time, degradation of both $n$-alkanes and isoprenoid occurred in the samples. 

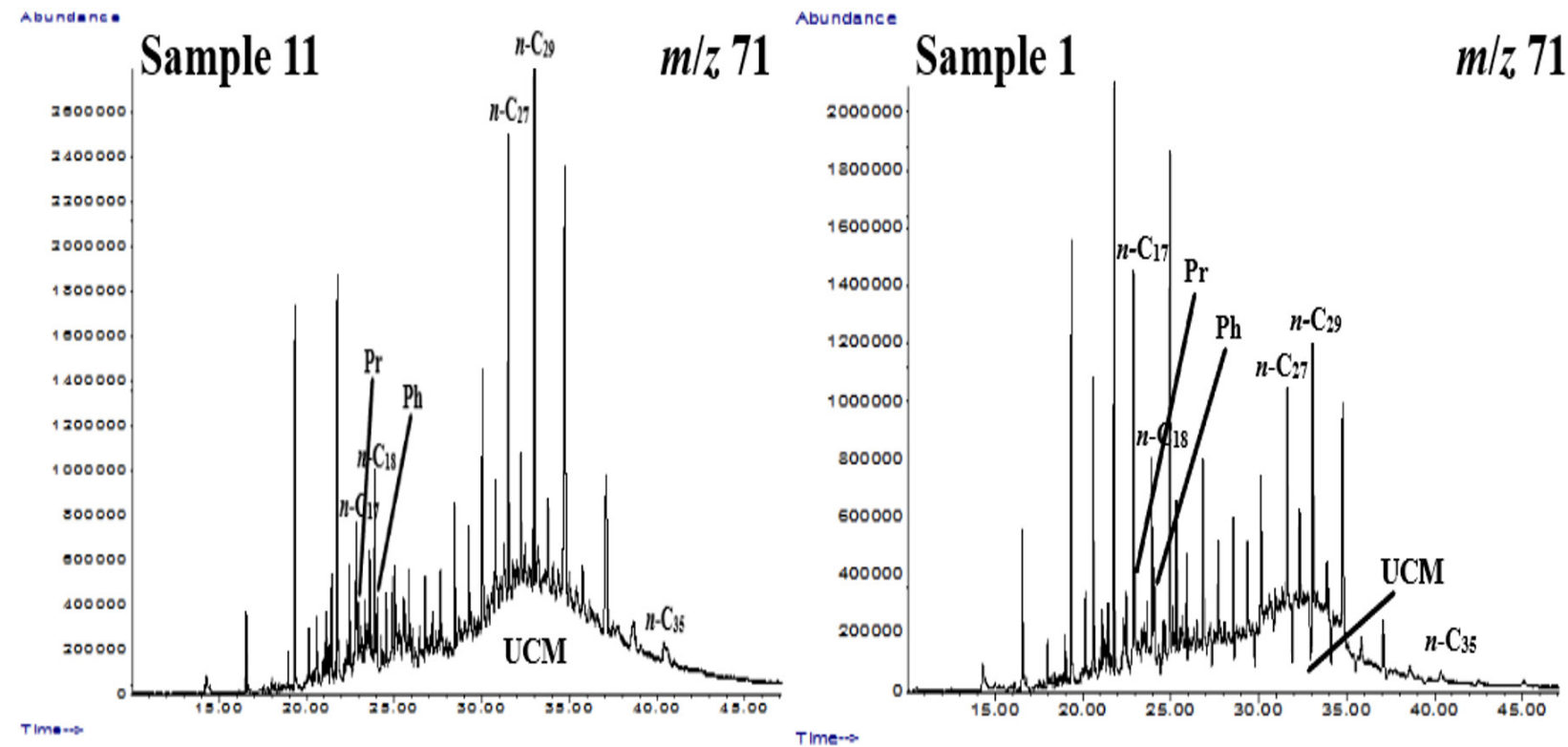

Fig. 2. Chromatograms of selected $m / z$ ratios 71 characteristic for $n$-alkanes in samples 11 and 1 .

Tab. 2. Characteristic correlation parameters of saturated hydrocarbons in sediment and soil samples.

\begin{tabular}{ccccccc}
\hline Sample & $\mathbf{C P I}^{\mathbf{a}}$ & $\mathbf{P r} / \mathbf{P h}$ & $\boldsymbol{n}$ - $\mathbf{C}_{17} / \mathbf{P r}$ & $\boldsymbol{n}$ - $\mathbf{C}_{18} / \mathbf{P h}$ & $\boldsymbol{n}$-Alkanes range & Most abundant $\boldsymbol{n}$-alkanes \\
\hline 1 & 2.2491 & 0.9884 & 3.3875 & 1.8715 & $\mathrm{C}_{12}-\mathrm{C}_{35}$ & $\mathrm{C}_{16} ; \mathrm{C}_{19}$ \\
2 & 1.5767 & 0.9993 & 2.8479 & 1.7826 & $\mathrm{C}_{12}-\mathrm{C}_{35}$ & $\mathrm{C}_{19} ; \mathrm{C}_{22}$ \\
3 & 2.6383 & 1.1242 & 1.5224 & 2.2195 & $\mathrm{C}_{12}-\mathrm{C}_{35}$ & $\mathrm{C}_{27} ; \mathrm{C}_{29}$ \\
4 & 1.9284 & 1.2290 & 1.5272 & 1.9709 & $\mathrm{C}_{12}-\mathrm{C}_{35}$ & $\mathrm{C}_{14} ; \mathrm{C}_{16}$ \\
5 & 1.3981 & 0.9868 & 1.7802 & 1.6554 & $\mathrm{C}_{12}-\mathrm{C}_{35}$ & $\mathrm{C}_{13} ; \mathrm{C}_{16}$ \\
6 & 2.5811 & 1.0730 & 1.2290 & 1.2427 & $\mathrm{C}_{12}-\mathrm{C}_{35}$ & $\mathrm{C}_{27} ; \mathrm{C}_{29}$ \\
7 & 1.6120 & 0.9796 & 1.3851 & 1.4975 & $\mathrm{C}_{12}-\mathrm{C}_{35}$ & $\mathrm{C}_{27} ; \mathrm{C}_{29}$ \\
8 & 2.1728 & 1.0863 & 1.2418 & 1.2712 & $\mathrm{C}_{12}-\mathrm{C}_{35}$ & $\mathrm{C}_{16} ; \mathrm{C}_{29}$ \\
9 & 2.0567 & 0.9495 & 1.1449 & 1.1695 & $\mathrm{C}_{12}-\mathrm{C}_{35}$ & $\mathrm{C}_{27} ; \mathrm{C}_{29}$ \\
10 & 1.4164 & 1.2134 & 2.0405 & 4.3249 & $\mathrm{C}_{12}-\mathrm{C}_{35}$ & $\mathrm{C}_{14} ; \mathrm{C}_{16}$ \\
11 & 1.9956 & 1.2771 & 3.8451 & 1.9327 & $\mathrm{C}_{12}-\mathrm{C}_{35}$ & $\mathrm{C}_{17} ; \mathrm{C}_{29}$ \\
12 & 2.5324 & 0.9601 & 1.8459 & 2.2834 & $\mathrm{C}_{12}-\mathrm{C}_{35}$ & $\mathrm{C}_{27} ; \mathrm{C}_{29}$ \\
\hline
\end{tabular}

${ }^{\mathrm{a}} \mathrm{CPI}=\frac{1}{2} \times\left(\frac{\mathrm{C}_{25}+\mathrm{C}_{27}+\mathrm{C}_{29}+\mathrm{C}_{31}+\mathrm{C}_{33}}{\mathrm{C}_{24}+\mathrm{C}_{26}+\mathrm{C}_{28}+\mathrm{C}_{30}+\mathrm{C}_{32}}+\frac{\mathrm{C}_{25}+\mathrm{C}_{27}+\mathrm{C}_{29}+\mathrm{C}_{31}+\mathrm{C}_{33}}{\mathrm{C}_{26}+\mathrm{C}_{28}+\mathrm{C}_{30}+\mathrm{C}_{32}+\mathrm{C}_{34}}\right)$

Chromatograms showing the presence of steranes $(m / z 217)$ and terpanes $(m / z 191)$ in representative samples are shown in Figs. 3. and 4., respectively. The presence of steranes and terpanes in recent sediments and soil samples indicates the presence of oil-type anthropogenic organic substances. Detector response for UCM is visible on the chromatograms of selected $\mathrm{m} / \mathrm{z}$ ratio 217 characteristic for steranes. Partial degradation of steranes and terpanes contributes to the total UCM content in all samples. As it can be seen from Fig. 3, distribution of terpanes in samples 11 and 1 does not differ significantly. Samples collected near the heating plant showed higher UCM content. Basic group of molecular fossils used in petroleum geochemistry is called polycyclic terpenoids (Belin et al., 2018). These alicyclic compounds originate dominantly from cell membranes of bacteria, microorganisms and algae, which are ubiquitous in sediments. The group includes several homologous series of tri-, tetra-, and pentacyclic triterpanes (Shirneshan et al., 2016; Paul and Dutta, 2106; Belin et al., 2018). The most commonly used alicyclic biomarkers are hopanes, which provide information on oil-sourcerock correlations (Grigoriadou et al., 2008). The most definitive indicators of petroleum contamination are probably $17 \alpha(\mathrm{H}), 21 \beta(\mathrm{H})$-hopanes (Rushdi et al., 2017; Hazra et al., 2019). Biological origin of $17 \alpha(\mathrm{H}), 21 \beta(\mathrm{H})$-hopanes has not been confirmed. However, $17 \alpha(\mathrm{H}), 21 \beta(\mathrm{H})$-hopanes are found in 


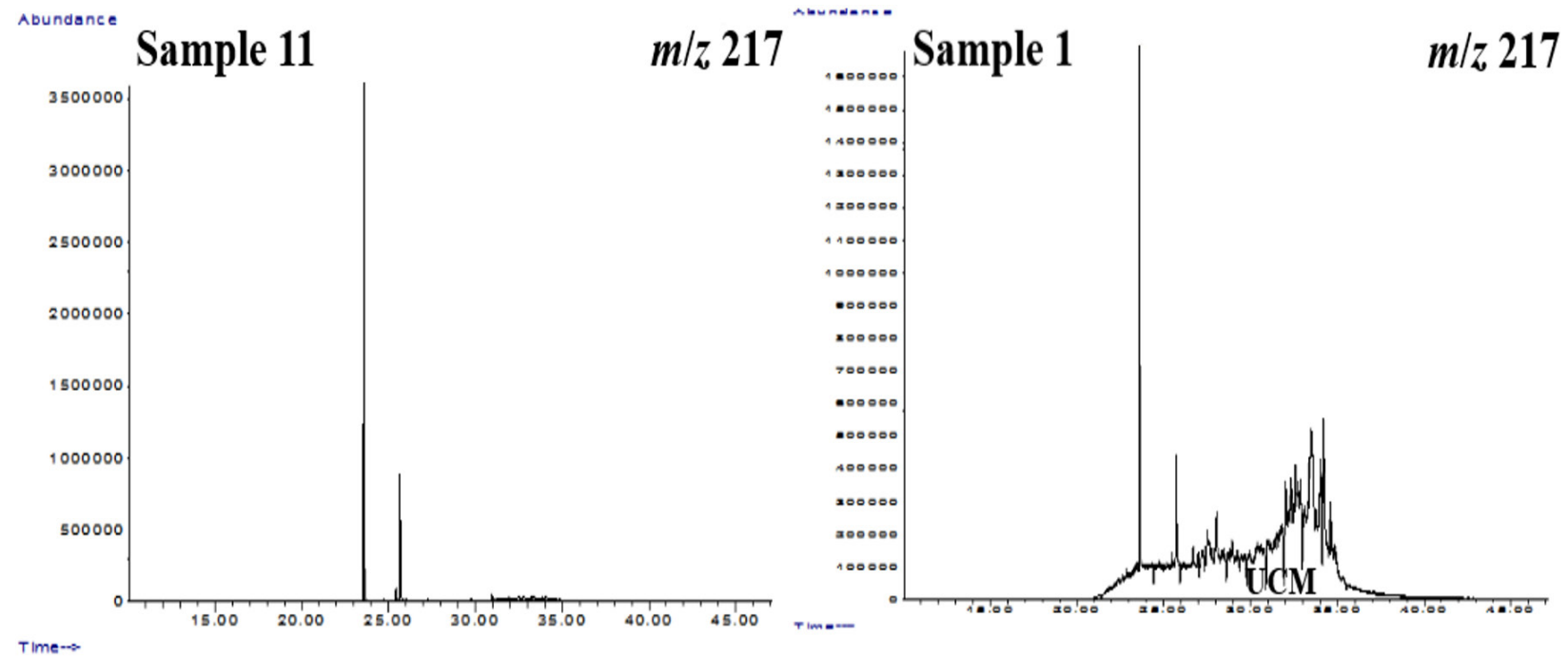

Fig. 3. Chromatograms of selected $\mathrm{m} / \mathrm{z}$ ratios 217 characteristic for steranes in samples 11 and 1.
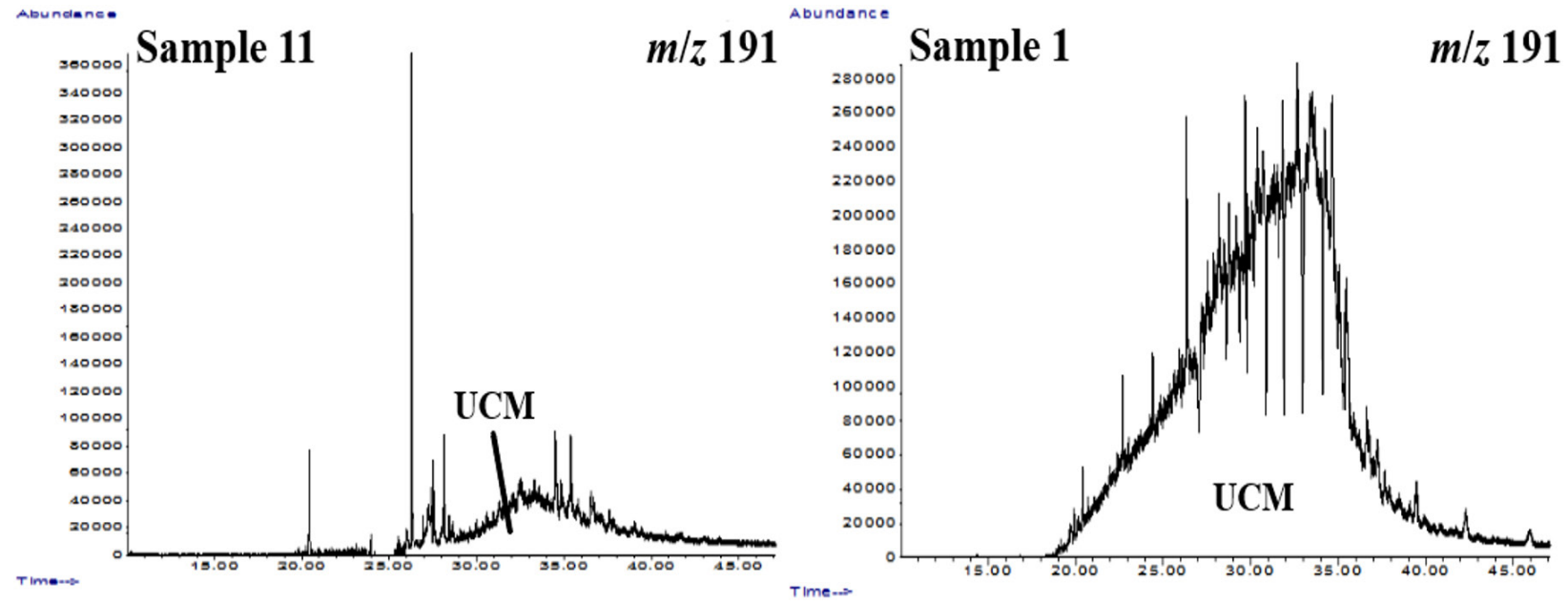

Fig. 4. Chromatograms of selected $\mathrm{m} / \mathrm{z}$ ratios $191 \mathrm{characteristic}$ for terpanes in samples 11 and 1.

petroleum and related sediments where they result from the isomerization of $17 \beta(\mathrm{H})$-hopanes (Inglis et al., 2018). In this case, the degradation pathway leads to relative depletion of $\alpha \alpha$ over $\beta \beta$ isomers, $\mathrm{R}$ over $\mathrm{S}$, and the removal trend $\mathrm{C}_{27}>\mathrm{C}_{28}>\mathrm{C}_{29}$ (Díez et al., 2005). Compared to terpanes, a slightly lower concentration of steranes was observed in all samples. The increase in sterane concentrations occurred only in samples 1 and 2 collected in the area of the city heating plant.

\section{Aromatic hydrocarbons}

Due to their environmental impact and toxicity, aromatic compounds have proven to be very useful as indicators of the fate of petroleum pollutants in the environment and as specific source markers of petroleum pollutants in sediments, tissue samples of living organisms and water (Jafarabadi et al., 2017 and 2019; Ghribi et al.,
2019; Han et al., 2018). Aromatic compounds identified in the samples belong to a group of bicyclic and tricyclic aromatic hydrocarbons. Bicyclic aromatic hydrocarbons include alkylated naphthalene derivatives: methyl-naphthalenes $(\mathrm{m} / z$ 142), dimethyl- and ethyl-naphthalenes $(\mathrm{m} / \mathrm{z}$ 156) and trimethyl-naphthalenes $(\mathrm{m} / z$ 170). The presence of alkylated phenanthrene $(\mathrm{m} / \mathrm{z} 178)$ and anthracene $(\mathrm{m} / z$ 178) derivatives like methylphenanthrene and methyl-anthracene $(\mathrm{m} / z$ 192), dimethyl- and ethyl-phenanthrene and dimethyland ethyl anthracene $(\mathrm{m} / \mathrm{z} 206)$ has also been reported. Individual chromatograms of bicyclic and tricyclic aromatic hydrocarbon compounds in samples 11 and 1 are shown in Figs. 5 and 6, respectively. Chromatograms of selected $\mathrm{m} / \mathrm{z}$ ratios characteristic for aromatic hydrocarbons and for saturated hydrocarbons are characterized by the presence of UCM. 


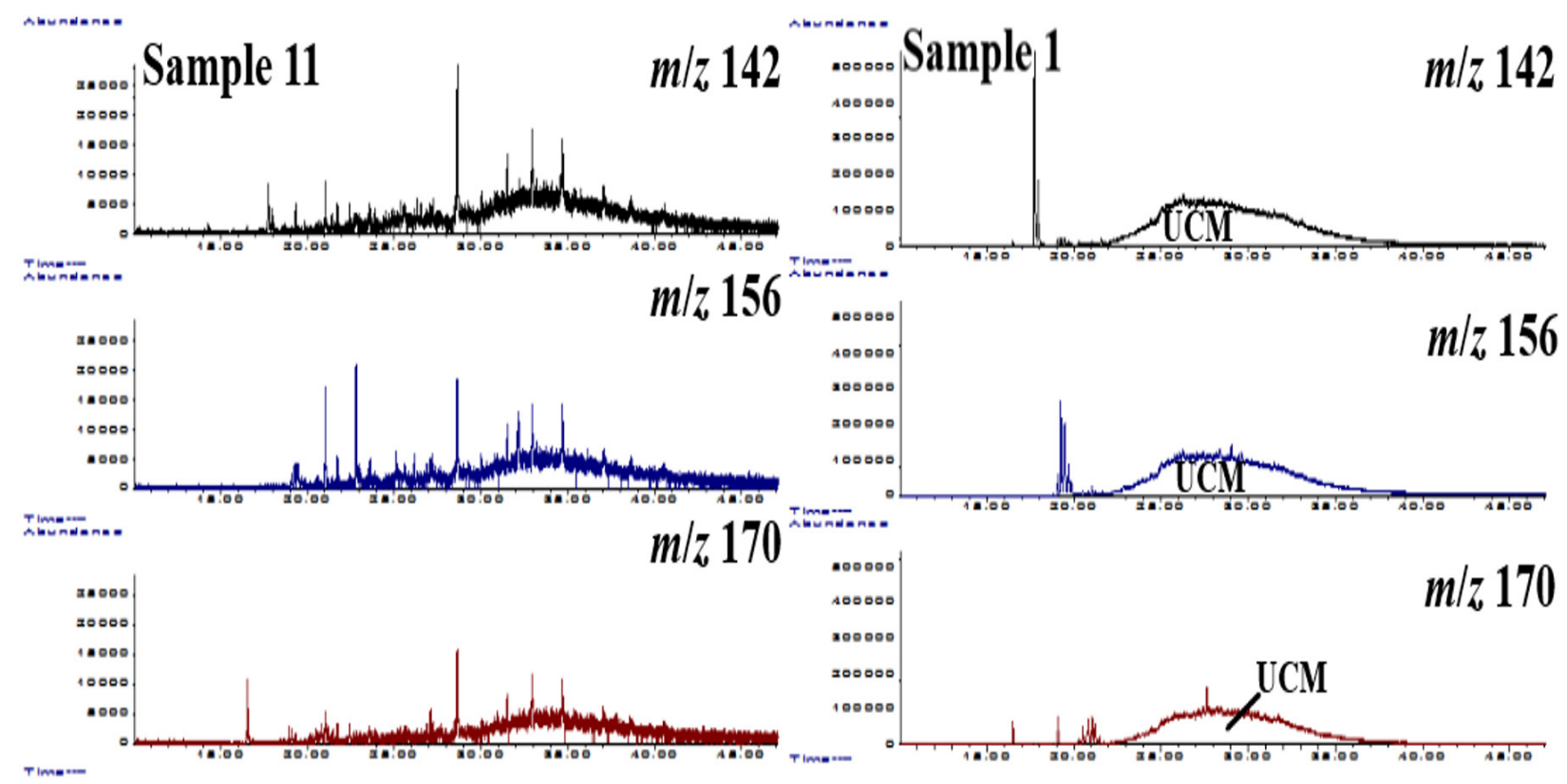

Fig. 5. Chromatograms of selected $\mathrm{m} / \mathrm{z}$ ratios characteristic for bicyclic aromatic hydrocarbons in samples 11 and 1.

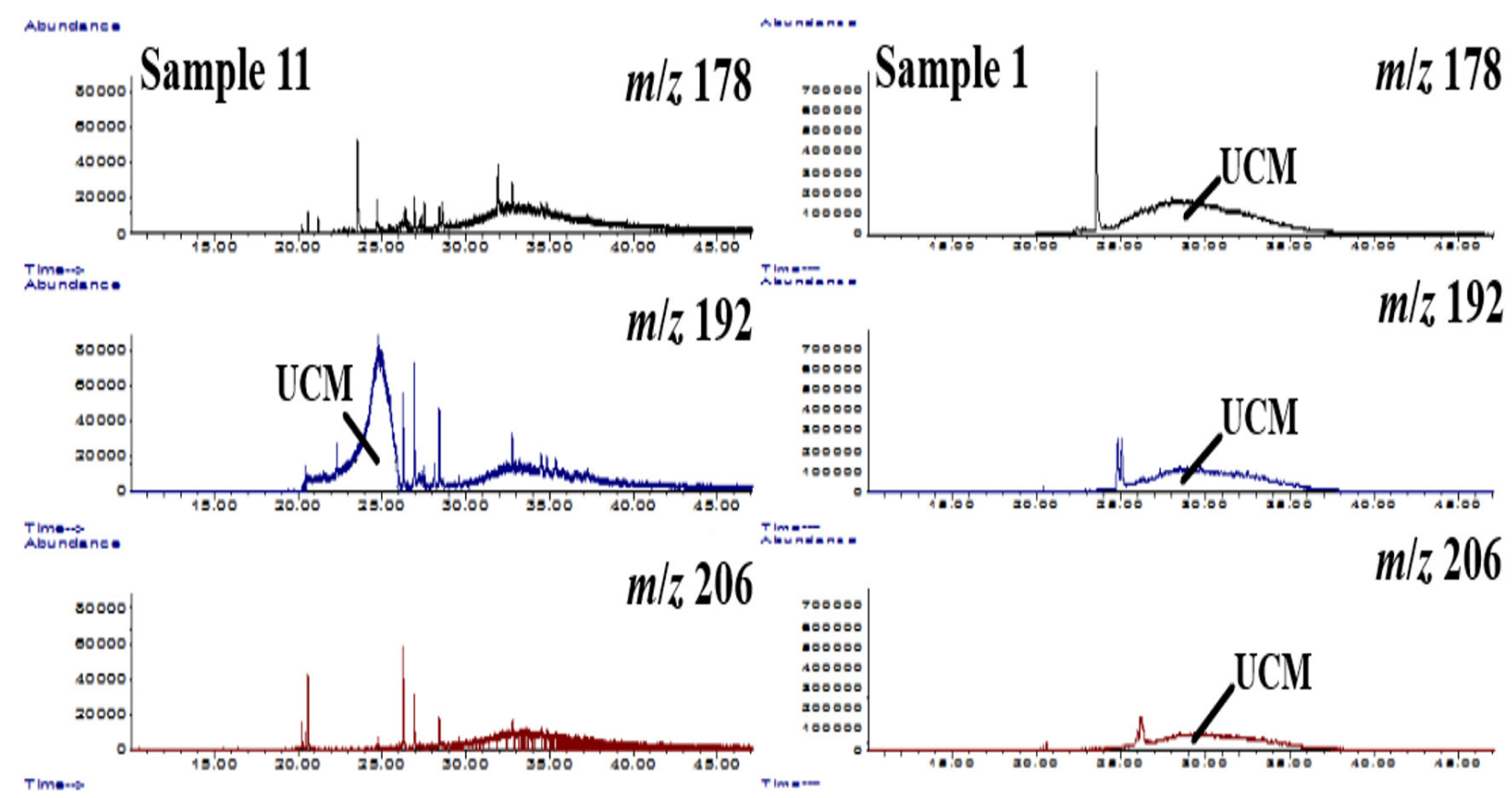

Fig. 6. Chromatograms of selected $\mathrm{m} / \mathrm{z}$ ratios characteristic for tricyclic aromatic hydrocarbons in samples 11 and 1 .

\section{Conclusions}

This paper investigates the origin and type of organic substances in sediment and soil samples taken in the area of the heating plant and the basin of the Vrbas river in the city of Banja Luka. The results confirmed very efficient TPH extraction by assisted solvent extraction. Characteristic correlation parameters were calculated by examining the $n$-alkane, sterane and terpane profiles in the sam- ples. CPI values were characterized by increased $n$-alkane content and the dominance of hydrocarbons with an odd number of $\mathrm{C}$ atoms. It has been shown that the obtained ratio of $n$-alkanes to isoprenoid alkanes indicates the presence of anthropogenic organic substances. This result indicates terrestrial organic contamination of anthropogenic origin. At the same time, microbial degradation of hydrocarbons was confirmed by the presence of UCM on chromatograms of saturated and aromatic 
hydrocarbons. Identification of steranes and terpanes in the samples also supports the assumption of the presence of oil-type anthropogenic organic substances in all samples. Polycyclic aromatic compounds from the group of bicyclic and tricyclic aromatic hydrocarbons were detected based on their characteristic $m / z$ ratios. PAHs also contribute to the UCM observed on the saturated and aromatic hydrocarbon chromatograms.

\section{Acknowledgement}

Nemanja Koljančic would like to thank the Visegrad fellowship program for contract number 51810301 allowing his ten months staying at the Slovak University of Technology in Bratislava.

\section{References}

Belin BJ, Busset N, Giraud E, Molinaro A, Silipo A, Newman DK (2018) Nat. Rev. Microbiol. 16(5): 304-315.

Cabrerizo A, Tejedo P, Dachs J, Benayas J (2016) Sci. Total Environ. 569-570: 1500-1509.

Catania V, Cappello S, Di Giorgi V, Santisi S, Di Maria R, Mazzola A, Vizzini S, Quatrini P (2018) Mar. Pollut. Bull. 131: 396-406.

Di Gregorio S, Siracusa G, Becarelli S, Mariotti L, Gentini A, Lorenzi R (2016) Environ. Sci. Pollut. Res. 23: 10587-10594.

Díez S, Sabatté J, Viñas M, Bayona JM, Solanas AM, Albaigés J (2005) Environ. Toxicol. Chem. 24(9): 2203-2217.

Faboya OL, Sojinu SO, Sonibare OO, Falodun OT, Liao Z (2016) Environ. Forensics 17: 27-35.

Gdara I, Zrafi I, Balducci C, Cecinato A, Ghrabi A (2020) Arch. Environ. Contam. Toxicol. 78: 1-19.

Ghribi R, Correia AT, Elleuch B, Nunes B (2019) Arch. Environ. Contam. Toxicol. 76: 678-691.

Grigoriadou A, Schwarzbauer J, Georgakopoulos A (2008) J. Soils Sediments 8: 253-262.

Han Y, Nambib IM, Clementa TP (2018) Sci. Total Environ. 626: 795-806.

Hazra B, Wood DA, Mani D, Singh PK, Singh AK (2019) Sedimentary Biomarkers and Their Stable Isotope Proxies in Evaluation of Shale Source and Reservoir Rocks. In: Evaluation of Shale Source Rocks and Reservoirs. Petroleum Engineering. Springer, Cham.

He M, Moldowan MJ, Peters KE (2018) Biomarkers: Petroleum. In: White W. (eds) Encyclopedia of Geochemistry. Encyclopedia of Earth Sciences Series. Springer, Cham.
Iheonye C, Osuji LC, Onyema MO (2019) J. Appl. Sci. Environ. Manage. 23(4): 805-809.

Inglis GN, Naafs BDA, Zheng Y, McClymont EL, Evershed RP, Pancost RD, the 'T-GRES Peat Database collaborators' (2018) Geochim. Cosmochim. Acta 224: 249-261.

Jafarabadi AR, Bakhtiari AR, Aliabadian M, Toosi AS (2017) Environ. Pollut. 224: 195-223.

Jafarabadi AR, Dashtbozorg M, Mitra S, Bakhtiari AR, Dehkordi M, Cappello T (2019) Sci. Total Environ. 696: 133969.

Kakhki FV, Zakaria MP, Mohammadi M, Aris AZ, Tajik H (2018) Polycycl Aromat Compd (0): 1-17.

Kao NH, Su MC, Yen CC, Huang YJ (2018) J. Soils Sediments 19: 241-254.

Paul S, Dutta S (2016) Int. J. Coal Geol. 167: 65-74.

Romero IC, Schwing PT, Brooks GR, Larson RA, Hastings DW, Ellis G, Goddard EA, Hollander DJ (2015) PLoS One 10(5): e0128371.

Rushdi AI, Al-Shaikh I, El-Mubarak AH, Alnaimi HAJA, Al-Shamary N, Hassan HM, Assali MA (2017) Mar. Pollut. Bull. 124: 56-66.

Samelak I, Balaban M, Antić M, Šolević-Knudsen T, Jovančićević B. (2020) Environ. Chem. Lett. 18: 459-466.

Samelak I, Balaban M, Vidović N, Koljančić N, Antić M, Šolević-Knudsen T, Jovančićević B (2018) J. Serb. Chem. Soc. 83(10): 1167-1175.

Shirneshan G, Bakhtiari AR, Memariani M (2016) Environ Sci Pollut Res 23: 17484-17495.

Thermo Fisher Scientific Inc. (2011) Dionex ASE 150 Accelerated Solvent Extractor Operator's Manual. Thermo Fisher Scientific Inc., USA.

Tissot BP, Welte DH (1984) Petroleum Formation and Occurrence. Springer-Verlag, Berlin, Heidelberg, New York, Tokyo.

Vitorović D, Jovančićević B (2016) Fundamentals of Organic Geochemistry for students of the Faculty of Chemistry, University of Belgrade. Faculty of Chemistry, University of Belgrade.

Walters CC, Wang FC, Higgins MB, Madince ME (2018) Org. Geochem. 124: 205-214.

Wang G, Simoneit BRT, Shi S, Wang T, Zhong N, Wang P (2018) Acta Geol Sin-Engl 92(5): 1959-1972.

Yogaswara ED, Wulandari KI, Falahudin D (2020) The $3^{\text {rd }}$ International Symposium on Marine and Fisheries Research (3rd ISMFR) 147, 02002.

Zhu X, Mao S, Sun Y, Jia G, Wu N, Wu D, Guan H, Yan W (2018) J. Asian Earth Sci. 168: 155-162. 